\title{
TAFSIR AYAT CAHAYA DALAM MISYKĀT AL-ANWĀR DAN ORIENTASI PENDIDIKAN POTENSI DIRI
}

\author{
Oleh: Salahuddin*
}

\begin{abstract}
The term 'light' in Sufism has become a favourite terminology in different cases. It has been one of central themes in the work of 'sufi'. Al-Ghazāli proved his excellence when he interpreted the verses on light. The terms in those verses are interpreted as inner strengths of human such as senses, rationale, imagination, thinking, and intuition. These are lights by which the Almighty God leads human beings to get the fundamental light. This can, of course, be achieved by maximising human potentials through education.
\end{abstract}

KEYWORDS: Nūr, misykāt, mishbāh, zujājah, syajarah mubārakah, al-zaìt, nūr 'alā nūr

TULISAN ini akan memaparkan penafsiran al-Ghazālī terhadap ayat Cahaya dalam karya monumentalnya, Misykāt al-Anwwār. Ayat Cahaya yang dimaksud adalah salah satu ayat dalam Surah al-Nūr, tepatnya ayat 35 . Ayat ini sebetulnya sangat banyak mengilhami para sufi dan karena itu tidak heran jika tema cahaya kemudian menjadi salah satu tema sentral dalam beberapa karya para sufi. "Cahaya" dalam banyak hal menjadi konsep favorit terminologi spiritual (tasawuf) yang biasanya dilambangkan secara metafor (majāzì) dengan pengetahuan. Hakikat Allah sebagai Cahaya sebagaimana disebutkan dalam ayat 35 Surah al-Nūr di atas, telah mewariskan pengaruhnya terhadap spiritualitas Islam bukan hanya melalui mazhab Iluminasi (isyrāq), yang didirikan oleh sufi dan filosof, pada abad ke-6 H/12 M., Suhrawardī al-Maqtūl, melainkan juga dalam cabang Iluminasionis yang lebih umum yang dijumpai secara luas dalam berbagai bentuk dan mazhab tasawuf dan filsafat Islam. ${ }^{1}$

Dalam kaitannya dengan dunia pendidikan, penulis melihat bahwa apa yang dimaksud al-Ghazālī dengan istilah misykāt, mishbāh, zujājah, syajarah mubārakah, dan al-zaìt, dalam ayat cahaya sebagai daya-daya pada diri manusia sebagai jalan untuk meraih Cahaya Tuhan sangat sinkron,

* Doktor dalam bidang pemikiran Islam pada Sekolah Pascasarjana Universitas Islam Negeri Syarif Hidayatullah Jakarta ini adalah dosen tetap Fakultas Tarbiyah dan Keguruan UIN Alauddin Makassar. 
dan bahkan itu juga yang mesti dilatih, dididik, dan ditumbuhkembangkan dalam pendidikan. Namun, sebelum itu, penulis merasa perlu untuk memperkenalkan secara sekilas tentang karya yang sangat tipis dari al-Ghazālī ini dan arti penting karya ini.

\section{SEKILAS TENTANG MISYKĀT AL-ANWĀR}

Misykāt al-Anwār adalah sebuah karya yang secara khusus memfokuskan pembahasannya pada ayat cahaya (QS. Al-Nūr/24: 35) dan sebuah hadis tentang hijab. Kitab ini merupakan karya yang sangat menarik dari sudut pandang kehidupan batin dan pemikiran esoteris al-Ghazālī, yang memberikan gambaran yang sangat kental, dan mungkin juga unik, terhadap kehidupan dan pemikiran al-Ghazālī. Abū al-'Ilā 'Afīfī menyebutkan bahwa kitab ini menggambarkan sikap final al-Ghazālī dalam masalahmasalah yang telah dibahasnya dalam karya-karyanya terdahulu. Dalam kitab ini, ia dengan berani dan terang-terangan mengungkapkan apa yang tidak berani diungkapkannya dalam karya-karyanya yang lain. Dalam kitab ini, ia dekat kepada doktrin wahdat al-wujūd. Ia sampai kepada doktrin bahwa sebenarnya tidak ada yang ada dalam wujud ini kecuali Allah, karena wujud segala sesuatu selain Dia adalah pinjaman atau berasal dari Dia; wujud pinjaman apa pun berada pada hukum atau sifat apa yang tiada (fi hukm al-ma'dīm). Karena itu, alam pada hakikatnya tidak mempunyai wujud. ${ }^{2}$

Melalui karya ini, al-Ghazālī telah merintis teori filosofis iluminasionis (nazhariyyāh al-falsafiyyah al-isyrāqiyyah) sebelum al-Suhrawardī, Syekh al-Isyrāq mengembangkan mazhab filsafat ini dalam bentuk yang lebih sempurna. Dengan teorinya ini, al-Ghazālī menakwilkan ayat al-Nūr (QS. Al-Nūr/24: 35) dalam arti tidak mengambil makna lahirnya. Di sini alGhazālī memiliki pandangan esoterik dan filosofis yang radikal.

Sangat sulit menetapkan kapan kitab ini ditulis oleh al-Ghazālī, tetapi ia termasuk dalam kategori kitab-kitabnya yang akhir, dan mungkin termasuk yang paling akhir. Isyarat terpenting kita peroleh dari al-Ghazālī sendiri yang menyatakan bahwa kitab ini ditulis setelah karya terbesarnya, Ihyā' 'Ulūm al-Dìn. Selain itu, karya-karya al-Ghazālī lainnya yang disebutkan dalam kitab ini adalah Mi'yār al-'Ilm, Mahqu al-Nazar, dan al-Maqshad al-Asnā'.

Tujuan penulisan kitab ini dijelaskan al-Ghazālī sendiri dalam pengantarnya, yakni untuk menguraikan sebuah ayat al-Qur'an dan sebuah hadis, atas permintaan salah seorang murid terdekatnya. Ayat yang dimaksud adalah ayat tentang cahaya yang termasyhur (QS. Al-Nūr/24: 35) dan hadis yang dimaksud adalah hadis tentang hijab. Dengan demikian, tema umum Misykāt al-Anwār adalah metafisika cahaya. 


\section{POSISI PENTING MISYKĀT AL-ANWĀR}

Karya ini sebagaimana dikemukakan sebelumnya adalah sebuah karya al-Ghazālī yang paling esoteris, filosofis, dan radikal. Berbeda dengan Ihyä' yang merupakan salah satu dari etika sufi yang paling luas dan berpengaruh, karya ini lebih merupakan sebuah karya metafisika yang memfokuskan pembahasannya pada metafisika cahaya, dengan mengambil titik tolak ayat cahaya (al-Nūr ayat 35). Kalau Ihyä' merupakan buah paling menonjol dari upaya al-Ghazālī untuk memulihkan keseimbangan dan keselarasan antara dimensi eksoterik dan dimensi esoterik Islam, Misykāt merupakan karya khusus dimensi esoterik yang juga ditulis khusus atas permintaan muridnya yang terkhusus pula. Karya ini sama sekali tidak dimaksudkan untuk disebarluaskan bagi kalangan awam, karena itu berarti membeberkan ajaran al-Ghazālī yang paling esoterik. Dengan begitu, karya ini kurang populer dibandingkan dengan Ihyä' maupun karya al-Ghazālī yang lain. Karya ini hanya populer di kalangan para pengkaji dan praktisi sufi tingkat lanjut. Jadi, tidak salah jika melalui karyanya ini, para pengkaji tasawuf menyimpulkan bahwa tasawuf yang dianut oleh al-Ghazālī secara pribadi adalah tasawuf yang menurut klasifikasi para ahli disebut dengan tasawuf filosofis. ${ }^{3}$

Lalu, yang tidak kalah pentingnya, karya ini dipakai pula sebagai titik awal oleh kebanyakan sufi di kemudian hari untuk mengembangkan aliran teosofi dalam Islam, terutama sekali menginspirasi Suhrawardī alMaqtūl dalam menelorkan teori-teori mistis cahayanya melalui Hikmat alIsyrāq-nya. ${ }^{4}$ Kenyataan ini membuktikan bahwa tesis yang selama ini berkembang di kalangan Intelektual Islam bahwa al-Ghazālī-lah penyebab mundurnya kajian filsafat di dunia Islam mungkin perlu dikaji ulang.

\section{TAFSIR AYAT CAHAYA, AL-NŪR/24: 35}

Secara keseluruhan isi dari kitab Misykāt al-Anwār adalah upaya Imām al-Ghazālī untuk menafsirkan ayat 35 surat al-Nūr yang berbunyi:

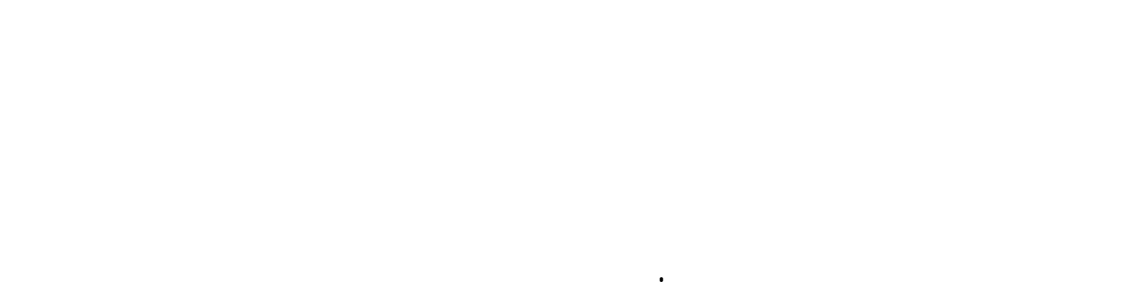

Allah adalah cahaya langit dan bumi. Perumpamaan cahaya-Nya adalah seperti relung atau ceruk (misykät/niche) yang di dalamnya ada sebuah lampu (mishbah), sedangkan lampu tersebut berada di dalam kaca (zujäjah). 
Adapun kaca tersebut adalah ibarat bintang-bintang gemerlap yang disulut dari sebuah pohon yang diberkati, sebuah pohon zaitun yang bukan Timur, bukan pula Barat, tetapi yang minyaknya akan menyala sekalipun tidak tersentuh oleh api. Cahaya di atas cahaya. Tuhan membimbing dengan cahaya-Nya itu siapa-siapa yang dikehendakinya. Ia memberi berbagai perumpamaan kepada manusia. Ia Maha Tahu segala sesuatu.

Berikut ini akan didiskusikan tafsir al-Ghazālī terhadap ayat di atas, khususnya yang berkenaan dengan beberapa istilah kunci: nūr, misykāt, mishbāh, zujājah, syajarah mubārakah, al-zaīt dan nūr 'alā nūr." Namun, mari dilihat apa yang dimaksudkan al-Ghazālī dengan cahaya tersebut. Cahaya didefinisikannya sebagai sesuatu yang terang atau tampak (al-zhāhir) pada dirinya dan bisa membuat yang lain terang atau tampak (al-muzhhir). ${ }^{5}$ Cahaya menurutnya memiliki beberapa tingkatan, dan berbagai istilah yang terdapat dalam ayat di atas adalah juga merupakan tingkat-tingkat cahaya yang dimiliki manusia dengan mana manusia terbimbing kepada kebenaran atau Tuhan. Di sini, ia menyandarkan filsafat hirarki cahayanya pada ungkapan yang ada dalam ayat di atas, "nūr 'alā nū r". ${ }^{6}$

Menafsirkan ungkapan "Allah adalah cahaya langit dan bumi," alGhazālī mengatakan bahwa Allah-lah satu-satunya yang bisa disebut cahaya, dalam arti yang sebenarnya, dan dalam hal ini Ia adalah unik dan tidak ada padanannya. Adapun cahaya-cahaya yang lain bisa disebut cahaya hanya secara alegoris (majāzì).7 Hanya Allah yang betul-betul ada, sedangkan keberadaan yang selain Allah adalah pinjaman, dan karena itu bukan wujud pada dirinya, tetapi wujud karena yang lain. ${ }^{8}$

Al-Ghazālī menafsirkan istilah-istilah lain selain cahaya yang dijabarkan secara panjang lebar, seperti misykāt, mishbāh, dan zujājah secara relatif singkat, tetapi sangat penting dan mengesankan. Bagi al-Ghazālī, istilah-istilah di atas, yakni, misykāt, mishbāh, zujājah, syajarah mubārakah, alzaìt, merujuk kepada (5) lima daya-daya ruhani manusia yang bercahaya (al-arwāh al-basyariyyah al-nūrāniyyah), ${ }^{9}$ yaitu jiwa indrawi (hissī), imajinasi (khayālì), daya rasional ('aqlī), daya reflektif (fikrī), dan (qudsī/nabawì). Lalu, seperti yang akan dijabarkan, penafsiran sufistik atas semua itu dilakukan dengan menarik paralelisme di antara keduanya.

Pertama adalah Misykāt. Misykāt, ditafsirkan al-Ghazālī sebagai dayadaya inderawi (al-rūh al-hisas), karena jika diperhatikan karakteristik daya jiwa ini, maka akan didapati cahayanya keluar dari berbagai lobang, seperti dua mata, dua telinga, dua lubang hidung dan lain-lain. Karena itu menurut beliau perumpamaan yang paling cocok dengan daya spiritual pada dunia lahiriah ini adalah ceruk atau misykät. ${ }^{10}$ Daya ini dapat menerima apa yang diberikan oleh panca-indera, dan ini dipandang sebagai 
akar dan penampakan pertama jiwa hewani, karena melalui inilah maka hewan menjadi hewan.

Beralih kepada mishbāh, al-Ghazālī menyamakannya dengan daya rasional (al-rūh al-'aqlì). Melalui daya ini, persepsi terhadap pengetahuan yang mulia dan ilahi dapat terjangkau. Perumpamaan daya akliah dengan lampu menjadi jelas, karena ia bisa menyebarkan cahayanya yang terang ke seluruh penjuru dunia, sebagaimana matahari yang memancarkan cahaya terangnya ke seluruh dunia, sehingga disebutnya "lampu-lampu yang memberi cahaya" (al-sirāj al-munìr), yang pernah dijadikan sebagai julukan bagi para Nabi.

Adapun zujājah (kaca) ia tafsirkan sebagai daya jiwa yang disebut imaginal (al-rūh al-khayālī), yang dipandang memiliki 3 (tiga) karakteristik atau ciri yang menyerupai kaca. Pertama, seperti kaca daya imaginasi masih terkait dengan, atau berasal dari, materi dunia rendah yang padat, karena benda-benda yang dikhayalkan memiliki ukuran, bentuk dan arah, dan juga jarak. Kedua, ketika imaginasi yang masih pekat ini dimurnikan, dihaluskan dan digosok, ia menjadi setara dengan makna-makna dan titiktitik rasional yang mengarah pada cahaya mereka. Imajinasi yang telah mencapai tingkat ini tidak akan merintangi cahaya yang datang dari lampu (mishbāh), yakni daya-daya rasional. Ketiga adalah pada mulanya imajinasi sangat dibutuhkan, karena melalui inilah seseorang dapat menyusun pengetahuan rasionalnya sehingga tidak terombang-ambing, tergoncang atau berserakan. ${ }^{11}$

Ketiga ciri ini, menurut pandangan al-Ghazālī, dapat ditemukan perumpamaannya di dunia lahir, hanya dalam kaca. Meski pada awalnya, kaca terbuat dari bahan yang pekat, tetapi sekali dimurnikan dan dibuat terang, maka ia tidak menghalangi cahaya sang lampu, bahkan ia mampu merambatkan cahaya tersebut dengan cara yang baik. Selain itu, ia juga memelihara cahaya dari terpaan angin kencang atau gerakan kasar yang bisa mematikannya.

Beralih kemudian pada "pohon yang diberkati" (syajarah mubārakah). Al-Ghazālī menyamakannya dengan jiwa reflektif (al-rūh al-fikrī). Seperti pohon, jiwa reflektif dimulai dengan sebatang akar dan kemudian muncullah darinya cabang-cabang, dan dari masing-masing cabang tumbuh dua cabang lainnya, dan dari tiap cabang tersebut tumbuh lagi dua cabang demikian seterusnya sehingga cabang-cabang ilmu rasional menjadi banyak. ${ }^{12}$ Akan tetapi, mengapa kemudian pohon yang diberkati tersebut disebut zaitun. Menurut al-Ghazālī, pohon zaitun memiliki keistimewaan di antaranya intisari dari buahnya dapat dibuat minyak zaitun, yang bisa dijadikan minyak bagi lampu. Sedangkan disebut diberkati (mubārakah) 
adalah karena dalam masyarakat Arab, ketika hewan piaraan atau pohon menghasilkan banyak turunan atau buah, maka mereka disebut mubārakah (diberkati). Karena itu akan lebih pantas untuk menyebut pohon yang buahnya tidak mengenal batas (daya reflektif manusia) dengan "pohon yang diberkati." Sedangkan disebut "tidak Timur dan tidak juga Barat (lā syarqiyyatan walā gharbiyyatan) adalah karena pemikiran-pemikiran murni rasional tidak bisa dikatakan memiliki arah, atau jarak dekat atau jauh, ${ }^{13}$ dan karena itu tidak pantas untuk disebut Timur atau Barat.

Terakhir, minyak zaitun akan menyala sekalipun tidak disentuh api (yakādu zaituhā yudhì'u walau lam tamsashu nār). Menurut al-Ghazālī, merujuk pada daya-daya suci/kenabian, yang dinisbatkan kepada para wali ketika ia mencapai tingkatnya yang paling mulia dan murni. Para filosof Muslim biasanya menjelaskan daya reflektif, kepada dua jenis. Pertama, yang membutuhkan pengajaran, penyadaran dan bantuan dari luar, sehingga ia dapat terus mengambil bagian dari banyak jenis ilmu pengetahuan. Kedua, karena memiliki kemurniannya yang begitu intens, ia tersadarkan dengan sendirinya tanpa bantuan dari luar. Yang terakhir inilah yang pantas disebut "minyak yang akan menyala sekalipun tidak tersentuh api" ${ }^{14}$ Begitu intensnya kemurnian mereka, sehingga di antara para wali, menurut al-Ghazālī, ada yang cahayanya bersinar demikian intensnya sehingga bisa terlepas dari bantuan Nabi, sebagaimana di antara para Nabi ada yang dapat terlepas dari bantuan malaikat. Tetapi kalau minyak tersebut disulut api, maka inilah yang disebut dalam ayat di atas "nūr 'alā nū r" (cahaya di atas cahaya). ${ }^{15}$

Dengan ini jelas bagi kita bahwa yang dimaksud dengan "cahaya" dalam ayat "Allah akan membimbing dengan cahayanya, siapa yang dikehendaki," bukan hanya berupa agama, sebagaimana yang sering dipikirkan, tetapi juga juga meliputi semua daya-daya jiwa yang dimiliki manusia, seperti indera, akal, imajinasi, daya fikir, dan intuisi. ${ }^{16}$ Dengan demikian dapat disimpulkan bahwa Allah membimbing manusia melalui indera, akal, imajinasi, dan hati atau intuisi. Karena itu kalau kita ingin mendapat bimbingan atau cahaya dari Allah, kita harus menggunakan daya-daya tersebut sebaik-baiknya.

\section{REFLEKSI PEDAGOGIS TERHADAP POTENSI DIRI}

Tidak pelak bahwa al-Ghazālī telah memberikan sumbangan yang sangat signifikan bagi dunia pendidikan. Tafsirannya mengenai term-term yang ada dalam ayat cahaya sebagai daya-daya jiwa yang ada pada diri manusia telah memberikan arah yang jelas tentang potensi yang perlu dikembangkan dan dimaksimalkan pada diri manusia. Dalam hal ini, al- 
Ghazālī ingin mengatakan bahwa sebelum menggunakan daya-daya yang ada pada diri sebagai syarat memperoleh bimbingan Allah swt, terlebih dahulu kita harus dapat melatih, mendidik, dan menumbuhkembangkannya sejak dini. Dengan demikian, seluruh potensi yang ada pada diri kita akan terdidik dan termaksimalkan. Masing-masing dari potensi itu, apabila dilatih dan dididik akan melahirkan manusia yang profesional dalam ragam dan bidang yang beraneka pula. Dengan potensi daya inderawi, daya akal, daya imajinasi, dan daya hati atau intuisi yang terlatih maksimal, maka akan lahir olah ragawan-olah ragawan ataupun saintissaintis yang handal, para pemikir atau pun para filosof yang mumpuni, seniman-seniman ataupun arsitek-arsitek dan spritualis-spiritualis atau sufi-sufi agung. Dengan demikian dapat dikatakan bahwa tafsiran alGhazālī ini telah memperkenalkan sejak dini apa yang ditemukan kemudian oleh para ilmuwan dengan sebutan kecerdasan IQ, EQ, dan SQ, atau yang disebut juga dengan pendidikan holistik. ${ }^{17}$

Karena potensi-potensi tersebut telah ada dalam setiap diri manusia, maka sangat dimungkinkan, meski mungkin sangat jarang, seseorang bisa menghimpun keempat keahlian tersebut dalam dirinya. Para sufi biasanya menunjuk Nabi Muhammad saw, sebagai manusia paripurna yang menghimpun keempat keahlian tersebut dalam dirinya. ${ }^{18}$ Setelahnya, kita dapat menemukan betapa banyak ilmuwan muslim yang memiliki lebih dari satu keahlian di dalam dirinya. Kita bisa menunjuk misalnya, Ibn Sina yang di samping dia seorang filosof, ia juga berprofesi sebagai seorang dokter yang handal. Bukunya, masih dikaji di fakultas-fakultas kedokteran dan telah ribuan kali dicetak ulang di negeri Barat sampai saat ini. ${ }^{19}$ Di abad ini, kita juga menemukan nama Hisyām Kabbānī, seorang Mursyid Tarekat Naqsyabandiyah, yang juga seorang ahli Fiqh dan ahli Fisika. Tentu saja, lebih banyak lagi yang mempunyai keahlian pada satu bidang saja.

Pada kenyataannya, dalam penelitian-penelitian psikologi ternyata, umumnya manusia hanya menggunakan tidak lebih dari 10\% dari potensi yang ada pada dirinya tersebut. Selebihnya yang 90\% kemana? Hasil penelitian ini menjadi bukti bahwa kebanyakan manusia belum memaksimalkan potensi dirinya tersebut. ${ }^{20}$ Namun yang lebih tragis lagi adalah, banyak manusia yang sama sekali tidak menyadari bahwa di dalam dirinya ada banyak potensi yang sangat luar biasa. Karena ketidaksadaran inilah, maka potensi yang banyak itu sama sekali tidak berkembang. ${ }^{21}$

Menyangkut dimensi pendidikannya, ada ketimpangan yang terlihat mencolok menyangkut proporsi pendidikan keempat dimensi dalam diri manusia. Kemerosotan moral yang terlihat di mana-mana, seperti korupsi, kolusi, penyalahgunaan jabatan, nepotisme, dan lain-lain, boleh jadi men- 
jadi bukti yang kuat bahwa potensi hati yang terabaikan. Di sisi lain juga, fenomena yang terlihat pada kalangan profesional saat ini, adalah mereka yang memiliki keahlian pada bidang tertentu seringkali mengklaim bahwa bidangnya itulah yang terbaik sembari meremehkan bidang-bidang lainnya. Sikap ini sebenarnya lebih merupakan sikap arogansi yang justru mengingkari potensi lain yang ada dalam dirinya.

Apa yang ingin dikatakan al-Ghazālì dalam hal ini adalah bahwa pendidikan harus berusaha menumbuhkembangkan dan memaksimalkan seluruh potensi yang ada pada diri manusia. Karena baginya, potensipotensi tersebut adalah cahaya-cahaya yang menjadi prasyarat bagi teraihnya cahaya atau bimbingan Tuhan.

Al-Ghazālī menyebutkan bahwa cahaya atau bimbingan Tuhan itulah yang akan diraih dengan memaksimalkan potensi-potensi yang disebutkan. Artinya, orientasi pendidikan seluruh potensi yang ada pada manusia harus diarahkan pada perolehan cahaya atau bimbingan Tuhan. Bimbingan Tuhan itu tidak lain adalah meraih jalan terdekat (jalan lurus) menuju kepada-Nya, yang telah disebutkan sebelumnya sebagai satu-satunya yang berhak disebut cahaya, sedang cahaya-cahaya yang selain-Nya hanyalah pinjaman belaka dari cahaya-Nya. Karena Ia adalah Cahaya Hakiki, maka cahaya-cahaya selainnya harus senantiasa mengacu dan menggantung pada-Nya untuk mempertahankan eksistensi kecahayaan-nya. Ini berarti bahwa manusia harus selalu menggantungkan diri dan menggantungkan harapan hanya kepada-Nya serta kembali menjadikan Tuhan sebagai sumber dan pusat orientasi kita. 22

Mencoba untuk berpisah dengan-Nya, apalagi berusaha untuk mencampakkan-Nya, akan melahirkan petaka-petaka besar kemanusiaan seperti yang telah terlihat di masa kini Al-Qur'an Surah Thāha (20): 124: menegaskan tentang hal ini,

Barangsiapa berpaling dari peringatan-Ku, maka sesungguhnya baginya penghidupan yang sempit, dan Kami akan menghimpunnya pada hari kiamat dalam keadaan buta.

Makna ayat tersebut adalah bahwa barangsiapa yang berpaling dari$\mathrm{Ku}$, tidak beriman kepada-Ku (kufur atas-Ku), dan tidak mengerjakan apa yang Kuperintahkan, maka sungguh baginya penghidupan yang sempit di dunia, lebih-lebih di akhirat kelak. Artinya, manusia tidak mungkin terpisahkan dari Tuhan. Manusia membutuhkan-Nya lebih dari yang ia kira. Spiritualitas Islam mengajarkan bahwa tanpa rahmat-Nya yang senantiasa tercurah, manusia tidak akan dapat berbuat apa-apa. Ayat di atas sekali lagi menegaskan bahwa krisis yang dihadapi manusia di zaman modern 
ini merupakan akibat "pemberontakan terhadap Tuhan." Mengutip pendapat almarhum E.F. Schumacher'23:

... Semakin banyak orang yang mulai menyadari "percobaan modern" yang berusaha memisahkan manusia dari tingkat-tingkat eksistensi yang lebih tinggi yang dapat mempertahankan keinsaniannya telah gagal. Manusia modern telah menutup gerbang-gerbang surga terhadap dirinya sendiri dan mencoba dengan daya kerja dan kecerdikannya yang luar biasa, mengurung diri mereka di bumi. Kini ia mulai mengetahui bahwa bumi hanyalah tempat persinggahan sementara, sehingga suatu penolakan untuk mencapai surga berarti secara sengaja sebenarnya turun ke neraka....

Jelas bahwa yang dimaksud oleh E.F. Schumacher dengan percobaan modern yang gagal itu adalah percobaan manusia untuk hidup tanpa Tuhan dan agama.

\section{PENUTUP}

Dari uraian di atas dapat ditarik beberapa kesimpulan sebagai berikut:

- Karya al-Ghazālī, Misykāt al-Anwār fi Tawhìd al-Jabbār, adalah sebuah karya yang unik dan berbeda dengan karya-karyanya yang lain. Karya ini adalah karya metafisika yang paling esoterik, filosofis, dan bahkan radikal.

- Penafsiran al-Ghazālī dalam karyanya ini berbeda dengan sejumlah penafsiran ulama sebelumnya. Term-term yang ada dalam ayat cahaya dipahami sebagai daya-daya jiwa yang dimiliki manusia, seperti indera, akal, imajinasi, daya pikir, dan intuisi. Daya-daya ini, menurutnya, adalah cahaya yang dengannya Allah membimbing manusia menuju Cahaya Yang Hakiki.

- Daya-daya indera, akal, imajinasi, daya pikir, dan intuisi sebagai cahaya akan menuntun dan membawa ke Cahaya Yang Hakiki, Allah swt. bila daya-daya tersebut dimaksimalkan lewat upaya pendidikan.

\section{CATATAN AKHIR:}

1. Lihat Annemarie Schimmel,, Mistical Dimension of Islam, Chapel Hill: The University of Carolina Press, 1975, h. 267.

2. Abū al-'Ilā 'Afîfī, "Tashdīr 'Amm," dalam Abū Hāmid al-Ghazālī, Misykāt alAnwār, diedit dan diberi pengantar oleh Abū al-'Ilā 'Afîfī, Kairo: al-Dār alQawmìyah, 1964, h. 7.

3. Klasifikasi tasawuf ke dalam tasawuf akhlakī (sunnī) dan tasawuf filosofis sangat bersifat normatif dan diskriminatif, dan tidak dapat diterima oleh kajian ilmiah yang bersifat deskriptif atau non-normatif. Kautsar Azhari Noer 
mensinyalir bahwa klasifikasi ini sangat disukai oleh para pendukung tasawuf sunni, dan kata "sunni" di sini bukan tanpa maksud. Paling tidak ada tiga maksud dari kata sunni di sini. Pertama, kata "sunni" menunjukkan bahwa tasawuf sunni adalah tasawuf yang diterima dan dianut oleh orang-orang Sunni (orang-orang yang menganut aliran Ahli Sunnah wal-Jamaah), yang mayoritas adalah para penganut aliran Asy'arīyah. Kedua, kata "sunni" menunjukkan bahwa tasawuf Sunni adalah tasawuf yang sesuai dengan sunnah, yang tentu saja sesuai dengan al-Qur'an. Ketiga, kata "Sunni" menunjukkan bahwa tasawuf Sunni, karena sesuai dengan al-Qur'an dan Sunnah, adalah tasawuf yang benar, lihat Kautsar Azhari Noer, Tasawuf Perenial: Kearifan Kritis Kaum Sufi, Jakarta: Serambi, 2002, h. 190.

4. Lihat Annemarie Schimmel, Mistical Dimension of Islam, Ibid. h. 267.

5. Al-Ghazali, Misykāt al-Anwār, h. 44

6. Ada contoh yang menarik tentang hirarki cahaya ini yang diberikan alGhazali. Misalnya cahaya yang kita terima dari bulan, tetapi yang terpantul lewat tembok. Cahaya yang berasal dari tembok, tentu tidak akan begitu terang, dibandingkan dengan cahaya yang dipantulkan oleh kaca kepada tembok itu. Demikian juga cahaya cermin yang dipantulkan ke tembok, tidak akan seintensif cahaya bulan yang dipancarkan kepada cermin tersebut. Namun cahaya bulanpun, kata al-Ghazali, tidak akan seintensif cahaya matahari yang dipancarkan ke bulan. Lihat Misykāt al-Anwār, Ibid. h. 55

7. Misykāt al-Anwār, Ibid., h. 56

8. Persepsi yang dipahami kaum khawāshsh ini bisa dipahami lebih dekat ke paham atau sama dengan pandangan dasar wahdat al-wujūd, yang memandang bahwa satu-satunya yang ada (wuju $\bar{d}$ atau exist) di alam semesta ini hanyalah Allah. Dilihat dari satu sisi, yang lain-manusia, dunia, dan seluruh keberadaan fenomenal lainnya - tidak benar-benar ada. Artinya, semuanya itu tidak berada secara terpisah dari-dan sebaliknya, sepenuhnya tergantung kepada-Allah. Dengan kata lain, kesemuanya itu merupakan bagian dariatau berpartisipasi dalam - wujud Allah. Yang selain Allah itu tampil sebagai (memiliki) wujud-wujud terpisah semata-mata hanya karena keterbatasan kemampuan persepsi manusia. Hanya saja persepsi ini lebih merupakan awal atau pondasi ke arah pemahaman terhadap wahdat al-wujüd.

9. Misykāt al-Anwār, h. 81.

10. Misykāt al-Anwār, h. 84.

11. Misykāt al-Anwār, h. 85.

12. Misykāt al-Anwār, h. 85.

13. Misykāt al-Anwār, h. 85.

14. Misykāt al-Anwār, h. 86.

15. Misykāt al-Anwār, h. 86.

16. Tidak sulit untuk memahami mengapa al-Ghazali menyebut daya-daya ini sebagai 'Cahaya'. Sebab daya-daya tersebut sebetulnya adalah alat-alat atau sumber-sumber pengetahuan (epistemologi) yang dalam bahasa hadis dikatakan bahwa ilmu itu adalah cahaya. Lebih jauh tentang daya-daya sebagai sumber pengetahuan ini, baca misalnya Mulyadhi Kartanegara, Menyibak Tirai Kejahilan: Pengantar Epistemologi Islam, Bandung: Mizan, 2003, h. 18.

17. Lebih jauh tentang berbagai kecerdasan ini, Baca misalnya, Ary Ginanjar 
Agustian, ESQ: Emotional, Spritual Quotient, (Jakarta: Penerbit Arga, 2001), dan Danar Zohar dan Ian Marshal, SQ: Spiritual Intelligence, The Ultimate Intelligence, London: Bloomsbury, 2000.

18. Dalam literatur-literatur sufi, Muhammad adalah manusia sempurna (al-insān al-kämil). Manusia sempurna adalah lokus penampakkan (mazhhar) diri Tuhan yang paling sempurna (Lihat Masataka Takeshita, Ibn 'Arabi's Theory of the Perfect Man and its Place in the History of Islamic Thought, Tokyo: Institute for the Study of Languages and Cultures of Asia and Africa, 1987.

19. Lihat Brian Hines, God's Whisper, Creation's Thunder: Echoes of the Ultimate Reality in the New Physic (Vermont: Treshold Books, 1996), h. 127 dst. Baca juga Mulyadhi Kartanegara, Tradisi Ilmiah Islam, Jakarta: Serambi, 2005.

20. Al-Qur'an membahasakan hal ini dengan ungkapan, "qalilan mā tasykurūn" sungguh sangat sedikit di antara kamu yang bersyukur. Ketidaksyukuran dalam hal ini tentu karena potensi luar biasa yang merupakan anugerah Ilahi itu tidak dimaksimalkan penggunaannya.

21. Bandingkan misalnya, seorang filosof dan penyair besar Islam, Moh. Iqbal, yang karena kesadarannya yang sangat dalam akan potensi diri yang sangat luar biasa ini sampai ia berucap, "Manusia bisa jadi apa saja kalau ia mau”.

22. Rujukan Qur' aninya sangat jelas, misalnya Q.S. al-An'ām (6): 162.

23. E.F. Schumcher, A Guide for the Perplexed, London: Abacus, 1981, h. 42. Baca juga Sayyed Hosein Nasr, Tasawuf: Dulu dan Sekarang, diterjemahkan oleh Abdul Hadi WM. dari Living Sufism, Jakarta: Pustaka Firdaus, 2000, h. 254.

\section{DAFTAR PUSTAKA}

Agustian, Ary Ginanjar, ESQ: Emotional, Spritual Quotient, Jakarta: Penerbit Arga, 2001

Ghazālī, Abū Hāmid al-, Misykāt al-Anwār fì Tawhīid al-Jabbār, diedit dan dianotasi oleh Samīh Dughaim Lebanon: Dār al-Fikr, 1994.

, Misykāt al-Anwār, diedit dan diberi pengantar oleh Abū al-'I'lā 'Afīfī, Kairo: al-Dār al-Qawmīyah, 1964.

Hines, Brian, God's Whisper, Creation's Thunder: Echoes of the Ultimate Reality in the New Physic, Vermont: Treshold Books, 1996, h. 127 dst.

Kartanegara, Mulyadhi, Menyibak Tirai Kejahilan: Pengantar Epistemologi Islam, Bandung: Mizan, 2003.

--------, Tradisi Ilmiah Islam, Jakarta: Serambi, 2005.

Nasr, S. Hosein, Tasawuf: Dulu dan Sekarang, diterjemahkan oleh Abdul Hadi WM. dari Living Sufism, Jakarta: Pustaka Firdaus, 2000.

Noer, Kautsar Azhari, Tasawuf Perenial: Kearifan Kritis Kaum Sufi, Jakarta: Serambi, 2002.

Schimmel, Annemarie, Mistical Dimension of Islam, Chapel Hill: The University of Carolina Press, 1975.

Schumacher, E.F., A Guide for the Perplexed, London: Abacus, 1981. 
Takeshita, Masataka, Ibn 'Arabi's Theory of the Perfect Man and its Place in the History of Islamic Thought, Tokyo: Institute for the Study of Languages and Cultures of Asia and Africa, 1987.

Zohar, Danar, dan Ian Marshal, SQ: Spiritual Intelligence, The Ultimate Intelligence, London: Bloomsbury, 2000. 